Journal of Contemporary Eastern Asia, Volume 11, No.2: 47-60

http://dx.doi.org/10.17477/jcea.2012.11.2.047

\title{
Reaction to Popular Pressure or a Political Tool? Different Interpretations of China's Policy Regarding Koizumi's Visits to the Yasukuni Shrine $^{1}$
}

Karol Zakowski

Sino-Japanese relations suffered a great setback during the premiership of Koizumi Jun'ichirō (2001-2006). Although many factors, such as dispute over the resources of the East China Sea or Japan's anxiety about China's growing military expenditures, are accountable for this situation, it was Koizumi's visits to the Yasukuni Shrine that became a symbol of the controversies between the two countries. The Yasukuni issue triggered a real eruption of profound anti-Japanese feelings among the Chinese people. While commentators in China accused Koizumi of glorifying militarism and whitewashing the atrocities committed by Japanese soldiers during the Second World War, the Japanese public started perceiving China's "exaggerated" reaction as a convenient diplomatic tool used by China to apply pressure on Japan in other bilateral disputes. On the one hand, spontaneous protests against Koizumi's visits to the Yasukuni Shrine constituted a great constraint in China's diplomacy towards Japan, but on the other, they also became an ideal pretext for adopting a tougher stance in Chinese foreign policy.

In this paper, I examine different points of view on the Yasukuni issue. After describing the Japanese background of the visits to the controversial shrine, I analyze various interpretations of China's reaction to the problem. Although emotions dominated discourse on the Yasukuni issue both in Japan and China, some pragmatic attempts to use this problem can still be seen. Besides being a side-effect of Koizumi's strong personality, the Yasukuni issue could be used either as a tool of factional struggle in the Chinese Communist Party (CCP) or as an instrument of Chinese foreign policy towards Japan.

\section{The Beginning of the Yasukuni Controversy}

The Yasukuni Shrine, situated near the Imperial Palace in Tokyo, was built in 1869 as a place glorifying all Japanese who died for their country and emperor. At first it was called Tokyo Shōkonsha, and acquired its present name in $1879 .^{2}$ The shrine quickly became a powerful symbol of Japanese patriotism. As portrayed in such war songs as Dōki no Sakura (Cherry Blossoms of the Same Years), soldiers who died on the battlefield used to believe that their souls would blossom as flowers on cherry trees in the gardens of Yasukuni. Having this in mind, it is easy to understand why the families of fallen soldiers wanted to commemorate their fathers, husbands or 
brothers by participating in yearly festivals in the shrine. It is also natural that Yasukuni became a stronghold of Japanese nationalism and revisionism.

Until the 1980s a great majority of postwar Japanese prime ministers, virtually without regard to their political beliefs, paid homage to the shrine on a yearly basis. ${ }^{3}$ Their visits did not become an object of any international controversy, even though class $\mathrm{B}$ and $\mathrm{C}$ war criminals convicted by Tokyo Tribunal had been enshrined in Yasukuni before the 1970s. ${ }^{4}$ The first prime minister who visited the shrine on August 15 was Miki Takeo. He visited in 1975 to commemorate the $30^{\text {th }}$ anniversary of Japan's surrender after the Second World War. Miki declared four principles of visiting Yasukuni in a private capacity: not to use official vehicle, not to make donations from public funds, not to use the title of prime minister, and not to be accompanied by public officials. Most of them were ignored by his successors. ${ }^{5}$ In 1978 class A war criminals were also enshrined in Yasukuni, which was probably the reason why the emperor ceased paying homage at the shrine. ${ }^{6}$ Nevertheless, prime ministers continued visiting Yasukuni without arousing any protests from China or South Korea.

The situation changed dramatically in 1985 when Prime Minister Nakasone Yasuhiro declared that he intended to pay an official homage at the shrine on August 15, the $40^{\text {th }}$ anniversary of Japan's surrender. By doing so he bent to the pressure of Nihon Izokukai (Japanese Association of Bereaved Families), an organization of the families of Japanese soldiers who died in the Second World War. ${ }^{7}$ Nakasone's initiative met with fierce protests from Beijing and Seoul, and the prime minister had to cease further visits to Yasukuni. His successors also did not want to anger neighboring countries and eschewed paying homage at the controversial shrine. The only exception was Prime Minister Hashimoto Ryūtarō who visited Yasukuni in 1996. It was not surprising, taking into account that he was a former chairman of Nihon Izokukai. Hashimoto explained that he paid homage to Yasukuni to fulfill a promise given as a child to his uncle and school teacher. ${ }^{8}$ Nevertheless, even he did not dare repeat his visit the next year.

Taking into account the cases of Nakasone and Hashimoto, Koizumi's determination to pay homage at the shrine on a yearly basis seemed unusual. There is no easy answer as to why Koizumi continued his visits even though he knew it would ruin friendly atmosphere in SinoJapanese relations. Before having become prime minister, Koizumi was not perceived as a representative of the right wing inside the Liberal Democratic Party (LDP). Although he was a member of Mori faction, a group dominated by nationalist politicians, instead of actively promoting such "hawkish" ideas as constitutional revision or remilitarization, he preferred to focus on economic policy. Since becoming a member of parliament in 1972, Koizumi used to visit the Yasukuni Shrine twice a year, but it was rather a gesture of gratitude to the generation of his father than a manifestation of radical nationalism. While he did not use the Yasukuni issue when he ran in the elections for the post of LDP leader in 1995 and 1998, the situation changed in 2001. Because his main opponent, Hashimoto Ryūtarō, ceased visiting Yasukuni after only one attempt in 1996, Koizumi decided to make the Yasukuni visitation issue one of the crucial points in his electoral campaign. He declared he would visit the controversial shrine every year on August 15 without regard to the criticism he would have to face. ${ }^{9}$ What is important is that the promise was officially sent by the Mori faction to branches of Nihon Izokukai all other the country. Thanks to this move, Koizumi could acquire the support of as many as 100,000 LDP members belonging to Nihon Izokukai who were disappointed with Hashimoto's behavior five years earlier. Although the votes of this group were not decisive in the election, they contributed to the scale of Koizumi's victory. ${ }^{10}$ 
On the other hand, it is hard to explain Koizumi's determination in visiting the Yasukuni Shrine only by his connections with Nihon Izokukai. Although the influence of the members of this rightist organization was much greater in the 1980s (the majority of them were the widows of soldiers fallen in the Second World War, so this group naturally diminished over time), they were unable to convince Prime Minister Nakasone to continue his visits to Yasukuni after the turmoil in $1985 .{ }^{11}$ Also, the hypothesis that Koizumi needed the support of the right wing in the LDP to privatize the Japanese post services seems unconvincing. Many of the most important "hawks" in the dominant party, such as Kamei Shizuka or Hiranuma Takeo, could praise Koizumi for his visits to the controversial shrine, but it did not stop them from condemning his economic policy or "despotic" style of leadership. ${ }^{12}$ Others, like former prime ministers Mori Yoshirō and Nakasone Yasuhiro, while agreeing that Japanese politicians have the right to visit Yasukuni, suggested that Koizumi should be more responsible and avoid further deterioration of relations with China. ${ }^{13}$

Obviously there were some other factors than the pressure of nationalist organizations that contributed to Koizumi's behavior. Against the principles of political realism, some authors find Koizumi's foreign policy irrational and prone to personal emotions. Uchiyama Yū even calls Koizumi a "prime minister full of pathos," because he never gave up his beliefs, even if it was against his political interests. ${ }^{14}$ It is true that Koizumi seemed very obstinate in pursuing the implementation of policies that constituted his electoral promises. One of the main objectives of his government was privatization of the Japanese postal service, which was contested by the majority of LDP members. Koizumi started appealing for the liberalization of the Japanese economy as early as the 1970s. ${ }^{15}$ Determination in pursuing this goal, and a belief that a politician should fulfill all of his electoral pledges was needed to privatize the post, but it ricocheted in foreign policy. The more Koizumi was pressed to cease visits to Yasukuni, the more he wanted to manifest his independence in decision-making.

No matter whether Prime Minister Koizumi was motivated by political interests or personal emotions, his regular visits to the controversial shrine became one of the main symbols of his premiership. The Yasukuni issue reemerged in a very sensitive period in Sino-Japanese relations. The economic ties between the two countries were becoming stronger, but the crisis in Taiwan Strait in 1996 had exhibited the dangers which threatened the stability in the region. Koizumi's emotional attitude towards his visits to Yasukuni clashed with a growing assertiveness of China on the international scene.

\section{China's Policy Regarding the Yasukuni Issue as a Reaction to Popular Pressure}

At the beginning of the $21^{\text {st }}$ century, China strove to reestablish friendly relations with Tokyo after the Taiwan Strait crisis and a disastrous visit by Jiang Zemin to Japan in $1998 .{ }^{16}$ One small step towards mutual understanding seemed to be made in October 2000, when Prime Minister Zhu Rongji displayed a more flexible posture on historical issues during his visit to Japan. In contrast to President Jiang, who had actively requested written apologies for the war atrocities from Prime Minister Obuchi two years earlier, Zhu, while repeating that written apologies still had not been made, emphasized that both countries should not excessively dwell upon the past. ${ }^{17}$ Nevertheless, Koizumi's plans to visit Yasukuni in 2001 endangered this delicate process of reconciliation by arousing anti-Japanese sentiments among the Chinese people. Under these circum- 
stances the leaders of the CCP had no choice but to return to a tougher stance on historical issues in relations with Tokyo.

There is no easy answer as to why Chinese citizens had become so sensitive about historical issues since the 1980s, and not directly after the Second World War. Commentators usually point to two main factors: an increasing level of social prosperity and freedom in China, and a decreasing level of legitimacy of the CCP. Beginning with the economic reforms, which were initiated by Deng Xiaoping in 1978, a new Chinese middle-class was born. Because China renounced radical initiatives, such as the Great Leap Forward (1958-1961) and the Cultural Revolution (1966-1976), its citizens were allowed more personal freedom than before. Under the rule of Mao Zedong the Chinese had much more prosaic problems to worry about than organizing anti-Japanese demonstrations. The public had no influence on the decisions of the CCP elite. Suffice it to recall the renunciation of war reparations by the Chinese government in 1972. It was not until the regime softened that the masses could start thinking about such initiatives as protests against the visits of Japanese prime ministers to the Yasukuni Shrine. Especially in the 1990s, the growing wealth of the Chinese people made them more confident in the power of their country, and more sensitive to any signs of the humiliation of China on the international scene. At the same time, the Internet provided them with an excellent means of expressing their sentiments. Despite the censorship of websites, the Internet made it more difficult for the authorities to monopolize the circulation of information. ${ }^{18}$ Due to these changes, public opinion became a factor which could no longer be disregarded by Chinese politicians. ${ }^{19}$ The commercialization of mass media only worsened the situation. To be competitive, numerous tabloids had to lure readers with more and more sensational news, but at the same time they could not criticize the establishment. Anti-Japanese comments became an effective way of getting the attention of newspaper readers without being subjected to censorship. ${ }^{20}$

The second factor concerned state policy. Together with the gradual introduction of a free market economy, communism became only a hollow slogan and the CCP leaders needed to find a new way of legitimizing their power. Due to the democratization of Taiwan, the communists no longer could refer to the Guomindang as an external threat, because it became a potential ally against the independence movement led by the Democratic Progressive Party. One way of legitimizing CCP rule and strengthening national solidarity was to bolster patriotism by educating Chinese society about the Japanese invasion during the Second World War. This began in the second half of the 1980s, but became especially visible in the 1990s, after the suppression of the student movement on Tiananmen Square in 1989. Until the 1980s the CCP leadership emphasized that the war atrocities had been a deed of a handful of militarists, not the whole Japanese nation. Peter Hays Green asserts that after initiating the program of reforms, the CCP changed its narrative about the war of resistance against Japan from "China as a victor" into "China as a victim." 21 The policy of building new Sino-Japanese war museums and introducing patriotic education into the schools resulted in the strengthening of anti-Japanese sentiments among the Chinese people. This policy however had its side-effects. Although it was conducted only on a domestic level, its results started influencing China's foreign policy.

Besides Koizumi's visits to the Yasukuni Shrine, there were also other events which aroused anti-Japanese emotions among the Chinese people at the beginning of the $21^{\text {st }}$ century. The problem of biased Japanese history textbooks emerged in 2001 and 2005. In 2003 there was a series of random events which triggered anti-Japanese demonstrations all over China. In August, one person died and many others were injured due to the accidental excavation of Japanese chemical weapons from the Second World War in Qiqihar. In September, just before the anni- 
versary of the Japanese invasion of Manchuria, Japanese businessmen organized an orgy in Zhuhai with the participation of hundreds of Chinese women. In October, Japanese students at Xi'an University performed a vulgar sketch which was interpreted as humiliating to China. In November, Toyota was accused of insulting China because of a commercial showing a Chinesestyle stone lion bowing to a Japanese vehicle. ${ }^{22}$ All of these often trivial events were treated as a proof that Japan once more wanted to subdue China and provoked violent demonstrations. Nevertheless, it was the Yasukuni issue that fueled anti-Japanese sentiments to the degree that even an insignificant incident could be interpreted as a deliberate attack on China's dignity.

In these circumstances it is natural that during Koizumi's premiership the image of Japan in the eyes of the Chinese suffered a severe deterioration. The rate of Chinese declaring hatred towards Japan rose steadily from $34 \%$ in 1997 to $53 \%$ in 2002 and $64 \%$ in 2005 . Furthermore, according to a survey from 2005 as many as $59 \%$ of Chinese citizens considered the Yasukuni Shrine mainly as a symbol of militarism, $15 \%$ as a place of mourning the war dead (compared to $66 \%$ of Japanese) and only $7 \%$ as a religious facility. ${ }^{23}$

Although partly responsible for this situation, the Chinese leadership tried to avoid an escalation of anti-Japanese protests. Because massive rallies easily change from the demonstrations of national solidarity against an external threat into manifestations of dissatisfaction with foreign policy, arousing popular sentiments can be a "double-edged sword." The leaders of the CCP could not afford an excessive deterioration in Sino-Japanese relations. The ability of sustaining high economic growth was an even more important source of legitimacy for the CCP than the recourse to patriotism, and economic cooperation with Japan contributed greatly to China's modernization. Beijing tried to prevent massive rallies whenever there was a real danger that they would have a negative impact on Sino-Japanese relations. For example, in September 1997 the CCP mobilized its forces to stop student demonstrations against Hashimoto Ryūtarō's worship at the Yasukuni Shrine, because they could disrupt his visit to China. ${ }^{24}$ On the other hand, to gain popular support the Chinese statesmen wanted to be perceived as patriots who defended the national interests and dignity of China, so they had to be "eager" enough in showing their "righteous indignation" towards Japan.

One of the best examples how popular protests against Koizumi's visits to Yasukuni influenced Chinese foreign policy was the case of a contract for a high speed railway linking Beijing and Shanghai. Although China intended since 2002 to import the Japanese technology of shinkansen, Koizumi's visits to the controversial shrine aroused a popular movement opposing this investment. In 2003, Chinese nationalists from the League of Patriots (Aiguozhe Tongmeng) started gathering signatures on an internet petition requesting to deny the Japanese offer. In just the first ten days of this action, they managed to collect 80 thousand signatures. This spontaneous initiative was evidently opposite to the interests of the Chinese authorities, which wanted to build the new railway on time for the Beijing Olympic Games in $2008 .^{25}$ The CCP leaders claimed that shinkansen was by no means related to Yasukuni, ${ }^{26}$ but pressed by popular protests they started postponing a decision in this matter. At the same time they kept giving signals to Japanese politicians visiting China, that the investment depended on the posture of Prime Minister Koizumi in regard to historical issues. ${ }^{27}$ Eventually the Japanese bid won in 2004, but it was a scaled down version of previous plans. This time Chinese authorities shut down the website which called for anti-Japanese protests. ${ }^{28}$ 


\section{Yasukuni Controversy as an Object of Debate inside the CCP}

The fact that Chinese politicians bent to popular pressure on the Yasukuni issue does not mean that there was always a consensus among them on the way China should react to this problem. Furthermore, historical issues in relations with Japan were used as a political tool in intra-party struggles. The situation inside the CCP has always been very non-transparent, but there still exist some hypotheses regarding factional rivalry in Chinese politics. Christopher H. Hughes emphasizes that in China "popular sentiments become a significant political factor when they are deployed in struggles at the top of the political system."29 Prime Minister Nakasone Yasuhiro admitted the main reason he ceased visiting Yasukuni after 1985 was because he feared that this problem could be used against the General Secretary of the CCP Hu Yaobang. Hu was a proJapanese politician and one of the leaders of a liberal faction in the party. ${ }^{30}$ What is interesting, is that it was two prominent Chinese statesmen $\mathrm{Gu} \mathrm{Mu}$ and Vice Premier Wan $\mathrm{Li}$ themselves who asked Nakasone through one of the Japanese delegations to China to stop visiting Yasukuni, because it undermined Hu's and their position in the CCP. ${ }^{31}$ Their concerns proved well-founded. In 1987, $\mathrm{Hu}$ was found responsible for the student demonstrations of 1986 and forced to resign. The communist hardliners accused him of a "bourgeois liberalization" and a too far-going rapprochement with Japan, symbolized by an invitation to China in 1983 of a group of 3,000 Japanese youth representatives. ${ }^{32}$

Taking into account that the Yasukuni issue had been used in the past as an instrument of factional struggle inside the CCP, Chinese politicians had to treat it with the greatest caution. When Koizumi became prime minister in 2001, the Chinese elites were on the verge of generational change. In November 2002, Jiang Zemin ceded the post of CCP general secretary, and in March 2003 also the post of CCP president, to a representative of the fourth generation of communist leaders, Hu Jintao. Nevertheless, he kept the posts of chairman of the CCP and PRC Central Military Commissions, and still exerted strong influence on the Chinese political scene. The CCP became an arena of struggle between two factions: a so-called "Shanghai clique" led by Jiang Zemin (in the 1980s he used to be mayor of Shanghai) and the camp of younger politicians led by $\mathrm{Hu}$ Jintao.

Jiang's faction, with such members as Zeng Qinghong, Wu Bangguo, Li Changchun, Jia Qinglin and Huang Ju, dominated the Politburo Standing Committee of the CCP. Zeng Qinghong,Vice-President of China since 2003, was especially believed to be the most influential subordinate of Jiang. What is interesting is that Zeng maintained good relations with many prominent Japanese politicians, especially with Nonaka Hiromu from the LDP. Also, at the beginning of Koizumi's premiership, he tried to promote friendly relations with Japan. Nevertheless, Jiang Zemin was rather a partisan of a tougher stance towards Japan, especially on historical issues. It was he who had started the campaign of patriotic education at the beginning of the 1990s and demanded written apologies for Japanese war crimes in 1998. For Jiang, bolstering patriotism was also a way of strengthening his position in the CCP. ${ }^{33}$

In contrast to Jiang's hard-line policy towards Japan, Hu Jintao did not want to excessively dwell upon historical issues. In the first half of the 1980s, he had been one of the main figures in the Communist Youth League of China, so he remembered $\mathrm{Hu}$ Yaobang's initiative to invite to his country a group of 3,000 young Japanese. Furthermore, one of the nearest associates of Hu Jintao was Wang Zhaoguo, who in the 1980s used to preside over the Sino-Japanese Committee of Friendship in the $21^{\text {st }}$ Century, established by Hu Yaobang to deepen mutual understanding between the two countries. Nevertheless, the fall of $\mathrm{Hu}$ Yaobang in 1987 taught $\mathrm{Hu}$ 
Jintao how treacherous maintaining friendly relations with Japan can be, especially during the reemergence of the Yasukuni issue. ${ }^{34}$

When Koizumi assumed the post of prime minister in 2001, control over Chinese foreign policy was still in the hands of the "Shanghai clique." It was not surprising that the first Koizumi visit to Yasukuni on August 13, 2001, met with firm protests from Beijing. The Chinese Foreign Ministry expressed "strong indignation" and emphasized that "the visit caused damage to the political foundation of Sino-Japanese relations and hurt the feelings of the Chinese and other Asian nations," as well as that it "will affect the future development of healthy bilateral relations." ${ }^{, 35}$ On the other hand, the fact that Koizumi took into consideration the requests of proChinese politicians in the LDP and renounced paying homage at the shrine on August 15, was a clear signal that he was ready for some limited concessions in this matter. ${ }^{36}$ In October 2001, the Japanese prime minister visited the Marco Polo Bridge near Beijing, where he admitted that he watched the exhibition with a feeling of "a regret and whole-hearted apologies to the people who became victims of aggression and war." 37 Jiang Zemin expressed dissatisfaction with Koizumi's previous visit to Yasukuni, but he avoided speaking about the homage at the controversial shrine the next year. It is probable that Jiang took the Japanese prime minister's conciliatory posture as a sign that Koizumi would confine himself to only one visit to Yasukuni, just as Nakasone and Hashimoto had done. ${ }^{38}$

This illusion did not last long. On April 21, 2002, Koizumi paid homage at the shrine once more. This time he did not discuss his visit with China, nor even with his nearest associates. The members of the "Shanghai clique" were furious. Prime Minister Zhu Rongji rspecially lost face, because he had failed to address the Yasukuni issue during his meeting with Koizumi at the Boao Forum for Asia on Hainan Island one week earlier. ${ }^{39}$ The anger of Jiang Zemin was attested to by Kanzaki Takenori, leader of Kōmeitō (party in coalition with the LDP), who visited Beijing at the end of April 2002. The PRC president called Koizumi's behavior "unforgivable" ( $b u$ neng yuanliang), which is a very strong remark in Chinese diplomacy. He evidently felt that Koizumi broke an unwritten gentleman's agreement not to visit Yasukuni again. ${ }^{40}$ Due to the resultant deterioration of the atmosphere improving bilateral relations, the Japanese prime minister had to postpone his visit to China, planned for autumn 2002. ${ }^{41}$ Koizumi's second homage at Yasukuni contributed to the hardening of "Shanghai clique's" policy towards Japan. When the Japanese prime minister met Jiang Zemin in October 2002 at the APEC summit in Los Cabos, Mexico, Jiang explicitly warned him not to visit Yasukuni in the future, but Koizumi did not relent. ${ }^{42}$

Even for Zeng Qinghong it was more and more difficult to promote friendly relations with Japan. In December 2002, Ma Licheng, an essayist linked with Zeng, published an article entitled The New Thinking on Japan, which provoked stormy discussions in China. Ma criticized anti-Japanese demonstrations and urged the Chinese not to dwell upon the past, but rather to focus on the future. ${ }^{43}$ If this article was Zeng's attempt to change national sentiments towards Japan, it ended in failure. On January 14, 2003, Koizumi Jun'ichirō paid homage at Yasukuni for the third time during his premiership, triggering further deterioration in Sino-Japanese relations. It is believed that he wanted to visit the controversial shrine as early as possible that year to avoid angering China at the beginning of Hu Jintao's presidency, scheduled for March $2003 .{ }^{44}$ It is true that Tokyo hoped that the generational change in the CCP would be a chance for a breakthrough in bilateral relations.

The first meeting between Koizumi Jun'ichirō and the newly elected President $\mathrm{Hu}$ Jintao took place at the summit in Saint Petersburg in May 2003. Hu displayed a much more flexible attitude towards Japan than Jiang Zemin. He not only thanked Tokyo for help in fighting 
SARS, but also proposed to establish a New Sino-Japanese Committee of Friendship in The $21^{\text {st }}$ Century, reviving $\mathrm{Hu}$ Yaobang's initiative from the 1980s. Importantly, Hu Jintao avoided mentioning the Yasukuni issue, which was a significant difference from Jiang's posture during the meeting in Los Cabos in 2002. The fact that Hu Jintao chose Zheng Bijian as chairman of the New Sino-Japanese Committee of Friendship in The $21^{\text {st }}$ Century was a sign that this new approach to Japan constituted part of a wider national strategy. That is because Zheng Bijian was a key thinker in the new government, who would later create a slogan of a "peaceful rising" (heping jueqi). ${ }^{45}$

Even though $\mathrm{Hu}$ Jintao wanted to reestablish a friendly atmosphere for Sino-Japanese relations, he could not ignore popular sentiment. When the temperature of anti-Japanese protests kept increasing in 2003, the possibility that the "Shanghai clique" would use the Yasukuni issue in the struggles inside the CCP became more and more real. To make matters worse, Koizumi's behavior started negatively influencing the political position of Hu's associates. When on October 7, 2003, Prime Minister Wen Jiabao met Koizumi in Bali, Indonesia, he hinted at the possibility of the resumption of mutual visits at the highest level, but the next day he was shocked to hear Koizumi's announcement that paying homage at Yasukuni no longer constituted an obstacle in Japan's relations with China. The Japanese prime minister not only confirmed he was going to visit the shrine the next year, but also suggested that the Chinese conceded on this matter. ${ }^{46}$ Due to Koizumi's statement, Wen Jiabao lost face inside the CCP, which resulted in the hardening of Beijing's attitude towards Japan. ${ }^{47}$ On January 1, 2004, Koizumi Jun'ichirō visited Yasukuni for the fourth time during his premiership, which as usual met with strong opposition from Beijing. ${ }^{48}$

Because soft policy towards Japan proved ineffective in persuading Koizumi to make any concessions on historical issues, intra-party criticism of the new government increased. Shimizu Yoshikazu estimates that the wave of anti-Japanese protests was especially advantageous for the members of the "Shanghai clique," because it provided them with a convenient tool for questioning Hu's authority. This situation weakened the PRC president's position in the CCP and forced him to renounce an active policy towards Japan. ${ }^{49}$ Nevertheless, Christopher H. Hughes emphasizes that Hu Jintao eventually managed to keep his leadership intact thanks to skillful power balancing in the CCP. For example, Hu won the support of a former ally of Jiang Zemin, Li Zhaoxing, by appointing him as foreign minister in 2003. As soon as Jiang ceded to $\mathrm{Hu}$ the chair of the CCP and PRC Central Military Commissions in September 2004 and March 2005, Hu could effectively suppress anti-Japanese demonstrations in April 2005. ${ }^{50}$ Thanks to his flexibility, he did not share the fate of Hu Yaobang.

\section{Instrumental Use of the Yasukuni Controversy in China's Diplomacy}

Because of the lack of transparency in Chinese politics, it is not easy to distinguish when Beijing merely reacted to popular pressure, or when, on the contrary, the authorities purposely sanctioned anti-Japanese protests to apply pressure on Japan. Nonetheless, a clear coherence between anti-Japanese manifestations and national interests of China can be seen as proof that in some cases the Yaukuni issue was used by Beijing as a convenient diplomatic tool. This hypothesis is propagated especially by right-wing Japanese activists and journalists who perceive China's protests as an interference in Japanese internal affairs. ${ }^{51}$ Many Japanese commentators find it suspicious that China had not protested against the visits to Yasukuni until 1985. One LDP politician, Hirasawa Katsuei, emphasizes that even though in 1979 there was extensive media coverage of 
the enshrinement of class A war criminals, Chinese leaders failed to signal their opposition. Hirasawa estimates it was the intention to use this problem instrumentally that brought about the diplomatic protests in 1985 . According to Hirasawa, "China is a haphazard country, which can take advantage of just anything in diplomacy." 52 Nevertheless, Hirasawa does not explain in detail what interest the Chinese government had in using the Yasukuni issue in its policy towards Japan at that time.

There are however some signs indicating that China utilized anti-Japanese protests to deny Japan a permanent seat in the UN Security Council. On March 21, 2005, General Secretary of the UN Kofi Annan announced there was a strong possibility that Japan would win a bid for a permanent seat, which provoked violent demonstrations all over China. The Japanese embassy in Beijing, as well as the general consulate in Shanghai, were assaulted with stones and bottles. Mobs attacked Japanese tourists and ravaged Japanese restaurants without causing much reaction by Chinese police. Even though the last homage at Yasukuni had been paid by Koizumi more than one year earlier, the anti-Japanese slogans of demonstration participants focused mainly on historical issues, including the Yasukuni issue. ${ }^{53}$ Nationalist websites initiated a large-scale action of collecting signatures on a petition against a permanent seat for Japan in the UN Security Council. They managed to collect 500,000 signatures by March 23, one million by March 25, 16 million by March 28 , and more than 41 million by April $28 .{ }^{54}$

Seki Hei claims that the anti-Japanese movement was able to spread so fast because it received tacit support from the Chinese authorities. ${ }^{55}$ On March 24, 2005, Liu Jianchao of the Chinese Foreign Ministry remarked that the action of collecting signatures against the Japanese bid for the permanent seat in the Security Council was not a matter of anti-Japanese sentiment, but "a request for Japan to adopt a right and responsible attitude on some historical issues." 56 Asked about China's stance on the UN reform Liu said: "We understand that Japan hopes to play a bigger role in international affairs. Meanwhile we hope that Japan adopts a correct and responsible attitude towards historical issues. You may have also noticed the Chinese public recently commented a lot on Japan's efforts." ${ }^{, 57}$ Liu Jianchao's statement was a clear signal that Beijing did not intend to suppress the manifestations. The Chinese authorities rejected Japanese requests for apologies for the damages caused by demonstrations and instead blamed Tokyo for an erroneous view of history. ${ }^{58}$ Furthermore, the state-run press agency Xinhua published in its magazine a letter sent to Kofi Annan by Tong Zeng, one of the leaders of the anti-Japanese movement. Tong evoked the Yasukuni issue as one of the main reasons why Japan was not responsible enough to become a permanent member of the Security Council. ${ }^{59}$ Even Prime Minister Wen Jiabao used the "history card" to disregard Japan. During his visit in New Delhi in mid-April 2005, he officially supported India's bid for a permanent seat, while emphasizing that: "Only a country that respects history, and takes the responsibility for it, can take greater responsibility in the international community." 60

Beijing never was really supportive of strengthening the Japanese position in the Security Council, and had no interest in a hasty suppression of the protests. On the contrary, popular protest was an ideal pretext for China to postpone the UN reform and prevent Japan from acquiring another symbol of power. ${ }^{61}$ Nevertheless, when the scale of demonstrations rose to an alarming level in mid-April 2005, the authorities decided to put an end to the protests. As mentioned before, it could have been also related to the fact that in the meantime Hu Jintao assumed the control over the PRC Central Military Commission and was confident that the "Shanghai clique" would not use anti-Japanese protests to question his authority. 
Even if it was not initially an intention of the Japanese or Chinese politicians, the Yasukuni issue made other Sino-Japanese controversies harder to resolve. A good example is the dispute over the seabed resources of the East China Sea. Japan contends that the border between the Exclusive Economic Zones (EEZ) of both countries should be designated in the middle of the sea, and China claims the sovereignty over the whole continental shelf up to the Okinawa Trough. Until the beginning of the $21^{\text {st }}$ century, the Chinese authorities confined themselves to exploiting only the gas fields near the Chinese coast, but in 2003 Chinese petroleum corporations started planning construction of an oil platform situated only 5 kilometers from the line which Japan considered its EEZ boundary. ${ }^{62}$ Tokyo protested, because there was a strong probability that China would extract oil from the Japanese side. The negotiations on this matter started in October 2004, but Beijing refused to share geological data which could verify Japanese suspicions. ${ }^{63}$ The talks ended in a deadlock partly due to the fact that Beijing feared that any concessions to Tokyo would be perceived as treason in Chinese public opinion. As with many other controversies, this dispute also quickly became a question of national pride. When Japan ordered its own geological survey on July 7, 2004, Chinese nationalists interpreted the date of this decision (the anniversary of the Japanese invasion of China in 1937) as a deliberate attempt to insult China. In September 2004, they even initiated a campaign of collecting signatures on a petition requesting that the government build aircraft carriers which could defend the seabed resources of China. ${ }^{64}$

Although these manifestations of patriotism were not organized by the authorities, they may also be regarded as a way of acquiring a better position in negotiations with Tokyo. The Japanese Minister of Economy, Trade and Industry Nakagawa Shōichi accused Beijing of purposely delaying the talks. ${ }^{65}$ As long as China exploited the disputed gas fields and Japan did not, it was in the interest of Beijing to maintain the status quo. During bilateral meetings at the end of September 2005, Japan proposed joint development of the disputed gas fields, but China rejected this offer. Koizumi's fifth visit to Yasukuni on October 17, 2005, triggered further deterioration in Sino-Japanese relations. Beijing refused to hold any high-level meetings with Tokyo, which meant that talks on the joint development of seabed resources had to be postponed until March $2006 .{ }^{66}$ Although there is no direct proof that China instrumentally used the Yasukuni issue to gain time in the negotiations, it did not stop Japanese politicians from accusing Beijing of treating the problem of the shrine as a diplomatic tool.

Nevertheless, making use of anti-Japanese emotions in diplomacy can be dangerous. The increase in anti-Japanese feelings among the Chinese people was one of the factors in Tokyo's decision to stop Official Development Assistance (ODA) yen loans to China. The lowinterest loans, initiated by Prime Minister Ōhira Masayoshi in 1979, contributed greatly to China's modernization. Since anti-Japanese protests in China increased, Japanese politicians argued that the yen loans became ineffective in promoting friendship between the two countries. Chinese society was not informed enough that such projects as the construction of Beijing airport were carried out thanks to ODA funds from Japan. Eventually, in March 2005, Foreign Minister Machimura Nobutaka decided that the loans would be ended until the opening of the Olympic Games in Beijing in 2008. ${ }^{67}$ It is interesting that the state-owned Xinhua press agency linked the problem of renunciation of the loans with Koizumi's visits to Yasukuni. ${ }^{68}$ It only proves that the issue of the controversial shrine has come to be a common way of explaining all disputes in Sino-Japanese relations, even those unrelated directly to historical issues.

Koizumi Jun'ichirō did not bend to the pressure of the international community nor to the criticism from the left wing of the Japanese political scene and visited Yasukuni for the last time as prime minister on August 15, 2006. By choosing the date of Japan's surrender after the 
Second World War he fulfilled his electoral oath from 2001. At a press conference, he emphasized that no matter what date he had chosen in the past, he kept being criticized, so visiting the shrine on August 15 would not make any difference. ${ }^{69}$

\section{Conclusion}

The impact that the Yasukuni issue had on Sino-Japanese relations during Koizumi's time as prime minister was a consequence of many factors. Koizumi's unyielding will to fulfill his electoral pledges clashed with a multi-faceted situation in China. At the beginning of the $21^{\text {st }}$ century, the Chinese people became much more sensitive to any signs of Japan's assertiveness on historical issues. China's reaction to the Yasukuni issue can be regarded mainly as a consequence of a growing nationalism in this country. Anti-Japanese emotions increased not only due to the commercialization of mass media, but also due to the patriotic education campaign initiated by the authorities at the beginning of the 1990s. Because of these changes, public opinion became a factor that the Chinese government could not simply ignore. The example of the shinkansen bid proved that popular protests, to a certain degree, could influence foreign policy.

Nevertheless, Beijing did not seek confrontation with Japan and tried to avoid escalation of the dispute. It does not mean though that the Yasukuni issue was not used within the CCP as a tool of inter-factional struggle. The example of the fall of Hu Yaobang had proved that the problems in relations with Japan, which emerged at a moment of crisis, could constitute an effective weapon in discrediting even the most influential Chinese politicians. Because Koizumi's visits to the controversial shrine coincided with a generational change in the CCP, a soft policy towards Japan could have undermined Hu Jintao's position in the party. It is clear that Hu's desire to make a new start in relations with Tokyo was disrupted by the pressure of Chinese public opinion and the "Shanghai clique." Eventually, Hu Jintao confirmed his leadership in the CCP, but he had to renounce his initial ideas for an active policy towards Japan.

Many commentators, especially Japanese politicians, claim that China used the Yasukuni issue as an instrument in diplomacy. It is true that in some cases China's interests could be in line with popular protests against Koizumi's visits to the shrine. The example of the demonstrations in spring 2005 shows that Chinese authorities were more willing to tolerate anti-Japanese incidents if they did not contradict China's diplomatic goals. On the other hand, even if historical issues made agreements in other bilateral disputes harder to achieve, it is not easy to state if it was due to the pragmatic use of the Yasukuni issue, or to the fear of diplomats that any concession to Japan would be treated as treason by the Chinese people.

\section{Notes}

${ }^{1}$ An earlier version of this paper was presented at the AAS/ICAS 7 Conference in Honolulu in April 2011. The author is grateful to the Polish Ministry of Science and Higher Education for financial support.

${ }^{2}$ Kobori Keiichirō, "Nihonjin ni totte 'Yasukuni Jinja' to wa Nanika" [What Is the "Yasukuni Shrine" for the Japanese?], in Kobori Keiichirō and Ōhara Yasuo, Yasukuni Jinja o Kangaeru 
[Thinking about the Yasukuni Shrine], (Tokyo: Nihon Seisaku Kenkyū Sentā, 2005), 2-4.

${ }^{3}$ Phil Deans, "Diminishing Returns? Prime Minister Koizumi's Visits to the Yasukuni Shrine in the Context of East Asian Nationalisms," East Asia 24 (2007): 272-274.

${ }^{4}$ Takahashi Tetsuya, Yasukuni Mondai [The Yasukuni Issue] (Tokyo: Chikuma Shobō, 2005), 65.

${ }^{5}$ Yomiuri Shinbun Seijibu, Gaikōo Kenka ni Shita Otoko. Koizumi Gaikō 2000 nichi no Shinjitsu [The Man Who Made Diplomacy a Quarrel. The Truth about 2000 Days of Koizumi's Diplomacy] (Tokyo: Shinchōsha, 2006), 233-234.

${ }^{6}$ John Breen, "Introduction: A Yasukuni Genealogy," in Yasukuni, the War Dead, and the Struggle for Japan's Past, ed. John Breen (New York: Columbia University Press, 2008), 1-4.

${ }^{7} \mathrm{Xu}$ Wansheng, Riben Zhengzhi yu Duiwai Guanxi [Japanese Politics and Foreign Relations] (Beijing: Renmin Chubanshe, 2006), 209-210.

${ }^{8}$ Sugiyama Toshiyuki, "Nitchū no Kakehashi wa Mikan" [The Bridge between Japan and China Is Unfinished], Nikkei Business, July 10, 2006, 13.

${ }^{9}$ Uchiyama Yū, Koizumi Seiken [The Koizumi Government] (Tokyo: Chūō Kōron Shinsha, 2007), 135.

${ }^{10}$ Yomiuri Shinbun Seijibu, op. cit., 222-223.

${ }^{11}$ In 1980 Nihon Izokukai could provide as many as 920 thousand votes in the elections to the House of Councilors, and only 170 thousand in 2004. See: Li Xiushi, Riben Xinbaoshouzhuyi Zhanlüe Yanjiu [A Study on Japan's Neo-Conservatism Strategy] (Beijing: Shishi Chubanshe, 2010), 230.

${ }^{12}$ Hiranuma Takeo, Shin Kokka Ron - Mattō na Nihon o Tsukuru tame ni [New Theory of State Towards Creation of a Respectable Japan] (Tokyo: Chūō Kōron Shinsha, 2005), 59-184; Kamei Shizuka and Namikawa Eita, Han'ei no Shinario [Scenario of Prosperity] (Tokyo: Chūkei Shuppan, 2003), 28-158.

${ }^{13}$ Mori Yoshirō. Jimintō to Seiken Kōtai [Mori Yoshirō. LDP and the Change of Power], ed. Iokibe Makoto, Itō Motoshige and Yakushiji Katsuyuki (Tokyo: Asahi Shinbunsha, 2007), 281282; Nakasone Yasuhiro et al., "Shōwa 80 nen" Sengo no Yomikata [The Way of Reading Postwar Period of the „80 $80^{\text {th }}$ year of Shōwa”] (Tokyo: Bungei Shunjū, 2005), 126-127.

${ }^{14}$ Uchiyama Yū, op. cit., pp. 176-182.

${ }^{15}$ Koizumi Jun'ichirō, Koizumi Jun'ichirō no Bōron - Seiron [Koizumi Jun'ichirō's Wild Arguments - Proper Arguments] (Tokyo: Shūeisha, 2001), 11.

${ }^{16}$ During Jiang Zemin's visit to Tokyo in 1998 Prime Minister Obuchi Keizō refused to issue formal written apologies for the crimes committed by Japan in the Second World War, causing strong dissatisfaction of PRC president. See: Lam Peng Er, "The Apology Issue: Japan's Differing Approaches Toward China and South Korea," American Asian Review, Vol. 20, No. 3 (2002): 48-50.

${ }^{17}$ Shimizu Yoshikazu, Chūgoku wa Naze "Hannichi” ni Natta no ka [Why Did China Become Anti-Japanese?] (Tokyo: Bungei Shunjū, 2005), 38-58; Zhong-Ri Guanxi 30 nian 1972-2002 [30 years of Sino-Japanese Relations 1972-2002], ed. Xu Zhixian (Beijing: Shishi Chubanshe, 2002), 281.

${ }^{18}$ Shih-Diing Liu, "China's Popular Nationalism on the Internet. Report on the 2005 Anti-Japan Network Struggles," Inter-Asia Cultural Studies, Vol. 7, No. 1 (2006): 144-149.

${ }^{19}$ Shimizu Yoshikazu, Chūgoku ga „Hannichi”" o Suteru Hi [The Day When China Renounces

“Anti-Japanism”] (Tokyo: Kōdansha, 2006), 149-150; Hong Junhao, "Wangluo Yulun yu 
Zhongguo de Waijiao Juece" [The Internet Public Opinion and China's Foreign Policy Making], in Zhongguo Waijiao Juece: Kaifang yu Duoyuan de Shehui Yinsu Fenxi [Chinese Foreign Policy Making: An Analysis of Societal Forces], ed. Hao Yufan, Lin Su (Beijing: Shehui Kexue Wenxian Chubanshe, 2007), 118-137.

${ }^{20}$ Shimizu Yoshikazu, Chūgoku wa Naze..., 174-178.

${ }^{21}$ Peter Hays Gries, China's New Nationalism. Pride, Politics, and Diplomacy (Berkeley - Los Angeles - London: University of California Press, 2004), 69-85.

${ }^{22}$ Mōri Kazuko, Nitchū Kankei: Sengo kara Shinjidai e [Sino-Japanese Relations: From the Postwar Period towards a New Era] (Tokyo: Iwanami Shoten, 2006), 189-190.

${ }^{23}$ Liu Zhiming, "Nitchū Komyunikēshon Gyappu to Jōhō Hasshin" [Sino-Japanese Communication Gap and Information Transmission], in Nitchū Sōgo Rikai no tame no Chūgoku Nashonarizumu to Media Bunseki [The Analysis of Chinese Media and Nationalism for the Sino-Japanese Mutual Understanding], ed. Takai Kiyoshi (Tokyo: Akashi Shoten, 2005), 107-109.

${ }^{24}$ Yinan He, "History, Chinese Nationalism and the Emerging Sino-Japanese Conflict," Journal of Contemporary China, Vol. 16, No. 50 (2007): 9.

${ }^{25}$ Hong Junhao, op. cit., 129.

${ }^{26}$ Shimizu Yoshikazu, Chügoku ga „Hannichi”..., 113.

${ }^{27}$ Yomiuri Shinbun Seijibu, op. cit., 255-257.

${ }^{28}$ Christopher P. Hood, "Bullets and Trains: Exporting Japan's Shinkansen to China and Taiwan,” The Asia-Pacific Journal: Japan Focus, accessed July 4, 2010, http://japanfocus.org/Christopher_P_-Hood/2367.

${ }^{29}$ Christopher H. Hughes, "Japan in the Politics of Chinese Leadership Legitimacy: Recent Developments in Historical Perspective," Japan Forum, Vol. 20, No. 2 (2008): 245-246.

${ }^{30}$ Seki Hei, „Nitchū Yūkō” wa Nihon o Horobosu! Rekishi ga Oshieru „Datsu Chūgoku” no Hōsoku [„Sino-Japanese Friendship” will Destroy Japan! The Principle of „Renunciation of China" Taught by History] (Tokyo: Kōdansha, 2005), 108-109.

${ }^{31}$ Nakasone Yasuhiro, Jiseiroku - Rekishi Hōtei no Hikoku to shite [Meditations - As Defendant in the Court of History] (Tokyo: Shinchōsha, 2004), 137.

${ }^{32}$ Shimizu Yoshikazu, Chūgoku wa Naze..., 125-127.

${ }^{33}$ Ibidem, 154-200.

${ }^{34}$ Ibidem, 194-195.

${ }^{35}$ Uchiyama Yū, op. cit., 136.

${ }^{36}$ Ming Wan, Sino-Japanese Relations: Interaction, Logic, and Transformation (Washington/Chicago: Stanford University Press, 2006), 237-242; Yomiuri Shinbun Seijibu, op. cit., 226232.

${ }^{37}$ Uchiyama Yū, op. cit., 137.

${ }^{38}$ Yomiuri Shinbun Seijibu, op. cit., 235-237.

${ }^{39}$ Ibidem, 240-242.

${ }^{40}$ Shimizu Yoshikazu, Chūgoku ga „Hannichi”..., 93.

${ }^{41}$ Ming Wan, op. cit., 247.

${ }^{42}$ Yomiuri Shinbun Seijibu, op. cit., 246-247.

${ }^{43}$ Ma Licheng, "Dui Ri Guanxi Xin Siwei" [The New Thinking on Japan], Zhanlüe yu Guanli 6 (2002), accessed July 8, 2010, http://qkzz.net/article/d854482b-05f0-45c7-8ee5f34801e8c5aa.htm. 
${ }^{44}$ Uchiyama Yū, op. cit., 140.

${ }^{45}$ Shimizu Yoshikazu, Chūgoku ga „Hannichi”..., 101-151.

${ }^{46}$ Yomiuri Shinbun Seijibu, op. cit., 253-254.

${ }^{47}$ Shimizu Yoshikazu, Chūgoku ga „Hannichi”..., 115.

${ }^{48}$ Sawa Kishirō, "Nitchū Kankei to Yasukuni Jinja Mondai no Honshitsu" [Japan-China Relations and the Essence of the Yasukuni Shrine Issue], Tōa Keizai Kenkyū, Vol. 63, No. 2-3 (2005): 6-7.

${ }^{49}$ Shimizu Yoshikazu, Chūgoku ga „Hannichi”..., 156-233.

${ }^{50}$ Christopher H. Hughes, op. cit., 256-258.

${ }^{51}$ For the examples see: Okazaki Hisahiko, Yayama Tarō, Yasukuni Mondai to Chūgoku [The Yasukuni Issue and China] (Tokyo: Kairyūsha, 2006); Okazaki Hisahiko, Kokka Senryaku kara Mita Yasukuni Mondai [The Yasukuni Issue Seen from the Perspective of State Strategy] (Tokyo: PHP Kenkyūjo, 2005).

${ }^{52}$ Hirasawa Katsuei, "Kokkai" no Butai Ura [The Backstage of the "Diet"] (Tokyo: PHP Kenkyūjo, 2006), 139.

${ }^{53}$ Tabata Mitsunaga, "Hannichi Demo wa Minzokushugi ka - Ikutsuka no Ronten Seiri" [Are the Anti-Japanese Demonstrations Nationalism? Arrangement of Some Points for Discussion], in Nitchü Sōgo Rikai no tame no.., 89-90.

${ }^{54}$ Liu Zhiming, op. cit., 125-126.

${ }^{55}$ Seki Hei, „Nitchū Yūkō”..., 134-135.

56 "Foreign Ministry Spokesman Liu Jianchao's Press Conference on 24 March 2005," accessed July 10, 2010,

http://big5.fmprc.gov.cn/gate/big5/www.mfa.gov.cn/eng/xwfw/s2510/2511/t188945.htm.

${ }^{57}$ Foreign Ministry Spokesman Liu Jianchao's...

${ }^{58}$ Ōnuki Hiroyuki, "Chūgoku ni okeru Kokka to Shakai no Henshitsu no Hōkō ni kansuru Kōsatsu - Sono 6" [Analysis of the Direction of Changes in Quality, in the State and Society of the People's Republic of China, Part 6], Reitaku Journal of Interdisciplinary Studies, Vol. 14, No. 2 (2006): 101.

${ }^{59}$ Seki Hei, ,Nitchū Yūkō”..., 136.

${ }^{60}$ Yomiuri Shinbun Seijibu, op. cit., 281.

${ }^{61}$ Ibidem, 281.

62 James C. Hsiung, "Sea Power, the Law of the Sea, and the Sino-Japanese East China Sea 'Resource War,"” American Foreign Policy Interests, Vol. 27, No. 6 (2005): 518.

${ }^{63}$ Uchiyama Yū, op. cit., 142.

${ }^{64}$ Yinan He, op. cit., 15-16.

${ }^{65}$ Uchiyama Yū, op. cit., 142.

${ }^{66}$ Mark J. Valencia, "The East China Sea Dispute: Context, Claims, Issues, and Possible Solutions," Asian Perspective, Vol. 31, No. 1 (2007): 132-134.

${ }^{67}$ Sekiyama Takashi, Nitchū no Keizai Kankei wa kō Kawatta. Taichū En Shakkan no 30 nen no Kiseki [The Sino-Japanese Economic Relations Changed That Much. 30 years of Yen Loans to China] (Tokyo: Kōbunken, 2008), 101-128.

${ }^{68}$ Ibidem, 117-123.

${ }^{69}$ Iijima Isao, Koizumi Kantei Hiroku [Secret Record from Koizumi’s Palace] (Tokyo: Nihon Keizai Shinbunsha, 2006), 316-317. 